\title{
Discovery of a ciliate parasitoid of euphausiids off Oregon, USA: Collinia oregonensis n. sp. (Apostomatida: Colliniidae)
}

\author{
Jaime Gómez-Gutiérrez ${ }^{1,4, *}$, William T. Peterson ${ }^{2}$, J. Frank Morado ${ }^{3}$ \\ ${ }^{1}$ College of Oceanic and Atmospheric Sciences, Oregon State University, 104 Ocean Administration Building, Corvallis, \\ Oregon 97331-5503 USA \\ ${ }^{2}$ NOAA/NMFS, Hatfield Marine Science Center, 2030 S. Marine Science Drive, Newport, Oregon 97365, USA \\ ${ }^{3}$ NOAA/NMFS, Alaska Fisheries Science Center, Resource Assessment and Conservation Engineering Division, \\ 7600 Sand Point Way NE, Seattle, Washington 98115-0070, USA
}

${ }^{4}$ Present address: Centro Interdisciplinario de Ciencias Marinas, Departamento de Plancton y Ecología Marina, Av. IPN s/n, A.P. 592, C.P. 23096, La Paz, Baja California Sur, México

\begin{abstract}
An apostome ciliate, Collinia oregonensis n. sp., is reported inhabiting the cephalothorax and abdomen of 3 euphausiid species from the Oregon-Washington coast: Euphausia pacifica Hansen, 1911, Thysanoessa spinifera Holmes, 1900, and Thysanoessa gregaria G.O. Sars, 1883. This ciliate is the 7th species described for the genus Collinia and the 2nd species known to infect euphausiids. Disease progression and ciliate morphology are described using (1) modified protargol stain, (2) hematoxylin counterstained with Fast Green, and (3) Scanning Electron Microscopy (SEM). All endoparasitic developmental stages (trophont, tomont, tomitogenesis, protomite, and tomite) of C. oregonensis are astomatous and possess between 14 and 22 kineties. C. oregonensis is smaller than C. beringensis Capriulo \& Small, 1986, which infects the euphausiid Thysanoessa inermis Krøyer, 1846 in the Bering Sea and which possesses between 24 and 80 kineties. The ciliate is a parasitoid because it must kill the host to complete its life cycle. Infections and mortalities in multiple host species likely reflect the virulent nature of the ciliate. Adult euphausiids infected with this parasitoid possess a swollen and bright orange cephalothorax. C. oregonensis feeds and proliferates inside euphausiids, producing fulminating infections that rupture the cephalothorax and release large numbers of tomites into the surrounding water. After several hours in the free swimming stage under shipboard conditions in the present study, the tomites adhered to each other, forming filaments. Infection rates ranged between 3 and $20 \%$ within individual euphausiid aggregations, but infected aggregations were randomly and sparingly distributed. Infected euphausiids were found at $6.7 \%$ of 316 stations sampled during 3 summer cruises. No infected euphausiids were collected in winter. Because E. pacifica and T. spinifera account for about $90 \%$ of the euphausiid standing stock in the northern California Current System, this parasitoid ciliate may have a significant impact on euphausiid population abundance, distribution and secondary productivity.
\end{abstract}

KEY WORDS: Euphausiids $\cdot$ Apostomatidae $\cdot$ Ciliates $\cdot$ Endoparasitoid $\cdot$ Colliniidae $\cdot$ Collinia Oregon coast

Resale or republication not permitted without written consent of the publisher

\section{INTRODUCTION}

Euphausiids, commonly known as krill, are a component of zooplankton and micronekton that dominate crustacean productivity of the world's oceans, especially in wind-driven coastal upwelling regions and the
Antarctic Ocean. Several euphausiid species are fished commercially, and are an important link between primary productivity and higher trophic levels in pelagic ecosystems (Nicol \& Endo 1999). The ecology and life cycles of euphausiids have been extensively studied, but sources of mortality are poorly understood. 
Gómez-Gutiérrez et al. (2003) and Gómez-Gutiérrez (2003, 2004) reported on an undescribed parasitoid ciliate of the genus Collinia responsible for a mass mortality of the euphausiid Euphausia pacifica Hansen, 1911 in Astoria Canyon, Oregon, USA. A parasitoid is an organism that must kill the host to complete its life history, sensu Lafferty \& Kuris (2002) and although the term is most frequently applied to an arthropod that infects another arthropod, a parasitoid may be any eukaryote meeting the above criterion. The present ciliate also infects 2 other euphausiid species along the Oregon-Washington coast: Thysanoessa spinifera Holmes, 1900 and Thysanoessa gregaria G.O. Sars, 1883, indicating that this parasitoid may infect other euphausiid species from the region or that similar ciliate-euphausiid relationships may occur worldwide. E. pacifica and T. spinifera are widespread and are the most abundant euphausiids along the northern California Current System, accounting for $\sim 90 \%$ of euphausiid abundance (Gómez-Gutiérrez et al. 2005). The character of the euphausiid mortality observed in Astoria Canyon challenges the widely held notion that mortality in pelagic organisms results primarily from predation and starvation (GómezGutiérrez et al. 2003), and ultimately also questions the traditional food web perspective (Dobson \& Hudson 1986). The significance of this discovery is that parasitoids may drive significant changes in the dynamics and secondary productivity of euphausiid populations. From a theoretical perspective, terrestrial parasitoids are able to regulate/affect their host populations; however, field results have been difficult to interpret (Hassell \& Godfray 1992). As a result, the impact of parasitoids on the population dynamics of zooplankton and food webs has been generally ignored or at least greatly overlooked by modern marine pelagic research.

The genus Collinia belongs to the order Apostomatida. All apostome ciliates live in a symbiotic relationship with marine invertebrates and those with known life cycles have major features in common (Fig. 1 from Bradbury 1966). Crustaceans are the most common, and probably the ancestral, hosts to apostomes. Apostome life histories are closely tied to the molting cycle of their crustacean hosts and are complex, involving an obligatory, polymorphic series of stages (Chatton \& Lwoff 1935, Trager 1957, Grimes \& Bradbury 1992). Apostome ciliate infections have been discovered on or in copepods, amphipods, isopods, ostracods, decapods, leptostracans, ctenophores, anemones, cephalopods (Chatton \& Lwoff 1935, Bradbury 1994, Morado \& Small 1995, Ohtsuka et al. 2004) and more recently in euphausiids (Capriulo \& Small 1986, Capriulo et al. 1991, Gómez-Gutiérrez et al. 2003). Endoparasitoid ciliates of the genus Collinia are well recognized as being among the most virulent of all apostome ciliates, having a fulminating lethal effect on the host (Morado \& Small 1995). Thus, it is predicted that members of this genus should be able to infect more than 1 host species to be stable in a parasitoid-host relationship. Indeed, the single ciliate species described here infects at least 3 common epipelagic euphausiids along the OregonWashington coast.

Infection of Thysanoessa inermis Krøyer, 1846 by a similar endoparasitic apostome ciliate, Collinia beringensis Capriulo \& Small, 1986, was previously discovered in the Bering Sea (Capriulo \& Small 1986, Capriulo et al. 1991). Because these 2 reports were based on preserved specimens, the appearance of infected euphausiids and the lethal effects of the ciliate could not be determined. The new ciliate species described here was discovered within the cephalothorax of 3 euphausiid species off the Oregon coast while experiments were being conducted on live euphausiids ( 1100 females incubated between 1999 and 2003) to estimate female egg production and molting rates (Gómez-Gutiérrez 2003). Live, infected euphausiids were collected and observed during shipboard incubations in order to describe the signs and progression of this parasitoidism. The present study is an extension of Gómez-Gutiérrez et al. (2003) and describes the morphology and life-stages of C. oregonensis n. sp. It also provides biological information on the possible impact of this parasitoid on euphausiid population abundance and distribution patterns in the California Current System.

\section{MATERIALS AND METHODS}

Sampling protocol. During an oceanographic cruise on the night of July 9, 2000, a Euphausia pacifica surface swarm was visually noted in which some individuals had an unusual orange and swollen cephalothorax $(n=21)$. After collection of several euphausiids with a 201 bucket it was discovered that they were infected with an unknown ciliate species. As part of the North East Pacific (NEP) US GLOBEC sampling program, more infected euphausiids were collected (see below) at night during 10 spring and summer oceanographic cruises between 2000 and 2003 along the Oregon Coast. These cruises were carried out on board the RV 'Wecoma' (Oregon State University, OSU) and the RV 'New Horizon' (Scripps Institution Oceanography, SIO). Live, infected euphausiids were observed during shipboard incubations at constant temperature and in darkness to study the progression of the ciliate infection. Live samples were captured with 4 different plankton nets during the night: (1) a $4 \mathrm{~m}$ long conical net with $333 \mu \mathrm{m}$ mesh net and a $1 \mathrm{~m}$ diameter mouth hauled from $20 \mathrm{~m}$ depth to the surface and designated 
'live net', (2) a multiple opening-closing net and environmental sensing system (MOCNESS) with $1 \mathrm{~m}^{2}$ mouth area and $333 \mu \mathrm{m}$ mesh net, sampling typically in 10 strata from $350 \mathrm{~m}$ depth to the surface, (3) a Bongo net with $200 \mu \mathrm{m}$ mesh net towed obliquely, and (4) a 201 bucket for surface swarms. Some infected specimens were preserved immediately upon collection with Bouin's fixative, $4 \%$ formalin buffered with sodium borate, $96 \%$ alcohol or $2 \%$ Lugol's solution. Most infected euphausiids were kept alive to be observed shipboard, and then preserved after death with Bouin's fixative.

Incubation and description of the ciliate. Live, infected euphausiids, identified by their orange and swollen cephalothorax, were transferred into 11 bottles filled with surface seawater and incubated on-board ship inside a cold room at $10^{\circ} \mathrm{C} \pm 0.5^{\circ} \mathrm{C}$ for several days until they died. This was the average temperature of the upper 15 to $20 \mathrm{~m}$ of the water column over the inner and middle shelf off Oregon. The euphausiids were monitored every 2 to $4 \mathrm{~h}$ during the night and every $6 \mathrm{~h}$ during the day for behavior, disease progression and time and manner of death. The sex of the euphausiids was determined by the thelycum (females) or the petasma in the first abdominal pair of appendages (males), and individuals were measured for total length $(\mathrm{mm})$ from behind the base of the eye stalk to the tip of the telson as soon as possible after collection. Sequential photographs of the external appearance of the host were taken using a digital camera $\left(3.3 \times 10^{6}\right.$ pixels resolution). After a euphausiid died, the ciliates inside the carcass and/or those swimming in the seawater were sampled every 2 to $4 \mathrm{~h}$ and preserved with Bouin's fixative to obtain ciliates in different developmental stages. To describe the different life-stages of the apostome ciliates inside the hosts we used (1) a modified Protargol staining technique (Tuffrau 1967), (2) hematoxylin counterstained with Fast Green (prepared by Stephen Landers, Troy University, Alabama), and (3) Scanning Electron Microscopy (SEM) of sagittal and transverse cuts of the euphausiids using a surgical knife after the specimen had dried. SEM micrographs were taken with an Amray 3300FE field emission scanning electron microscope at the Botany Department at Oregon State University (prepared by Al Soeldner, OSU).

Experimental infection. To determine the method of infection under laboratory conditions, groups of 10 to 15 healthy and apparently uninfected adult euphausiids were placed in 2.51 containers and exposed to (a) an infected, but live euphausiid, (b) a recently killed euphausiid that had burst and released all free-swimming tomites into the container, (c) a dead euphausiid that had not burst (but with ciliates remaining inside the body), (e) filaments of ciliates adhered to each other in a mucus matrix formed under laboratory conditions several hours after the euphausiid ruptured, and (e) control incubations without infected euphausiids to test if individuals from those particular sample stations were previously infected with the ciliates. The euphausiids were monitored at least every $6 \mathrm{~h}$ over a period of between 7 and $10 \mathrm{~d}$ to detect coloration. Preserved animals were dissected in the laboratory to search for ciliates in the hemocoel.

\section{RESULTS}

\section{Morphology of the life stages of Collinia oregonensis n. sp.}

The external morphological characteristics of the different endoparasitoid life-stages of Collinia oregonensis n. sp. are described from ciliates obtained from the cephalothorax of Euphausia pacifica and Thysanoessa spinifera using SEM (Figs. $1 \& 2$ \& Table 1). These are the first SEM micrographs taken of any species of the genus Collinia. The morphological characteristics of the parasitoid ciliates obtained from both euphausiid species indicate that these are the same ciliate species.

Trophont: Young trophonts measure about $35 \mu \mathrm{m}$ length in early infection. As each trophont grows (to 58-82 $\mu \mathrm{m}$ length and 13-51 $\mu \mathrm{m}$ width, 0.55 length/ width ratio) a total of 18,20 or 22 long, spiraling kineties develop (Figs. 1B \& 2B, Table 1) that extend the length of the cell. The cilia are so long that those from proximal kineties appear to overlap. The mature trophont stage is astomatous (no cytostome), with an oval anterior and rounded posterior end. As food accumulates within the cells, the trophonts become more robust, expanding to 2 times their original length and width until the cilia of proximal kineties fail to overlap. Protargol staining of the trophont stage shows that this stage possesses an elongate nucleus and very long cilia presenting a 'hairy' appearance (Fig. 3A,B). The shape of the trophont is dictated by how tightly packed the ciliates are in the cephalothorax (Fig. 3B). A schematic diagram of the trophont stage based on protargol staining indicates that at this stage the kineties closely join at the anterior end of the cell while they are more removed at the posterior end (Fig. 4A,B).

Tomont: SEM (Figs. 1D \& 2D) and silver impregnations (modified Protargol) (Fig. 5A) of the tomont reveal that it has a variable number of spiraling kineties, usually 20, but less frequently they have fewer (16 or 18). The tomont is astomatous, and cell size ranges from 12 to $58 \mu \mathrm{m}$ length and 12 to $33 \mu \mathrm{m}$ width, with a length/width ratio of 0.54 (Table 1). In live euphausiids with advanced infections, it is common to observe trophont and tomont ciliates swimming 

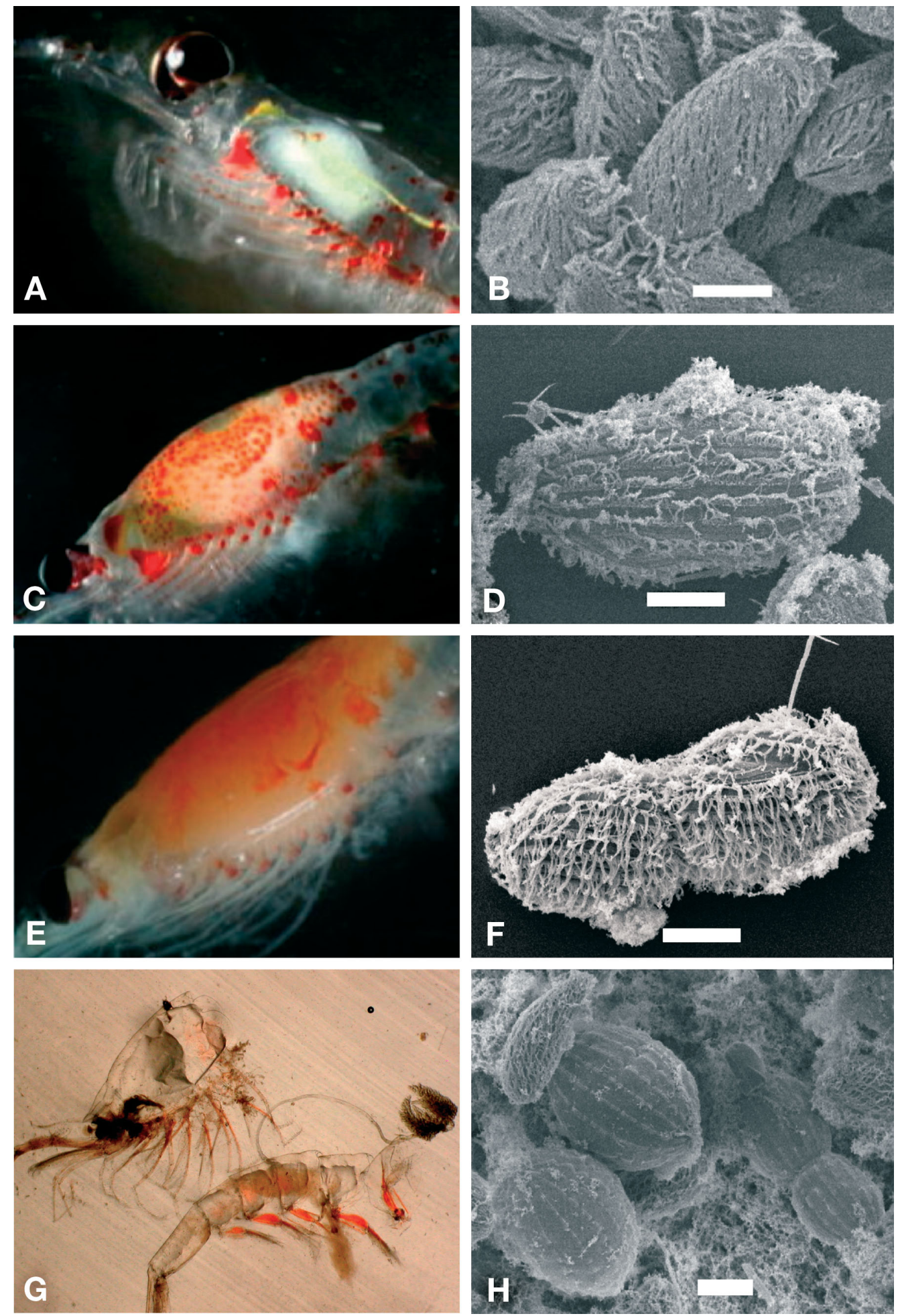

Fig. 1. Collinia oregonensis n. sp. infecting Euphausia pacifica. Ciliate morphology and chronological sequence of the infection of the host. (A) Adult euphausiid in early infection stage (12 to $24 \mathrm{~h}$ after the animal was observed to have a healthy appearance). (B) Young feeding stage (trophont) in early infection. (C) Intermediate infection with pale yellow and orange cephalothorax (10 to $15 \mathrm{~h}$ after pale coloration of carapace was observed). (D) Mature trophont stage. (E) Same specimen in an advanced infection phase. (F) Reproductive ciliate (tomont stage) ready to start palintomy - the ciliate starts cell division to produce transmission cells (tomites). (G) Euphausiid bursts after the ciliates digest the internal organs (35 to $55 \mathrm{~h}$ after pale coloration was observed).

$(\mathrm{H})$ Dispersion stage (tomite) at first division. Scale bars $=10 \mu \mathrm{m}$ 

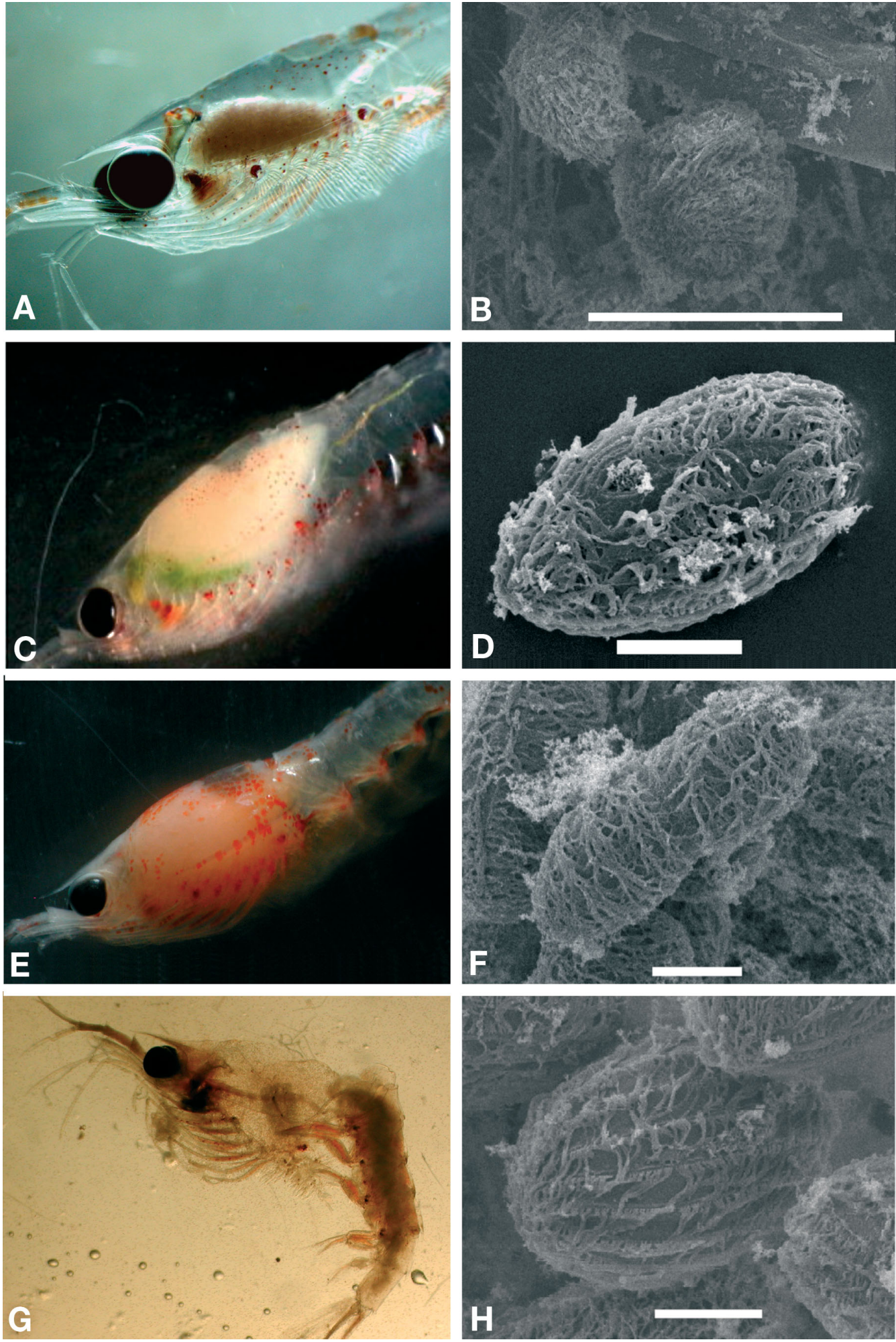

Fig. 2. Collinia oregonensis n. sp. infecting Thysanoessa spinifera. Ciliate morphology and chronological sequence of the infection of the host. (A) Adult euphausiid in early infection stage. (B) Young feeding stage (trophont) in early infection. (C) Intermediate infection with pale yellow and orange cephalothorax. (D) Mature trophont stage. (E) Same specimen in an advanced infection phase. (F) Reproductive ciliate (tomont stage) ready to start palintomy; the ciliate starts the cell division to produce transmission cells (tomites). (G) Euphausiid bursts after the ciliates digest the internal organs of the euphausiid. (H) Dispersion stage (tomite) at first division. Scale bars $=10 \mu \mathrm{m}$ 
Table 1. Morphometry of the parasitoid life-stages of the apostome ciliate Collinia oregonensis n. sp. (Apostomatida) which infects the euphausiids Euphausia pacifica, Thysanoessa spinifera and T. gregaria along the Oregon coast. Measurements are from micrographs obtained using a Scanning Electron Microscope $($ SEM). Trophont $=$ feeding stage, tomont = reproductive stage, tomitogenesis $=$ cells in division (palyntomy), tomite $=$ free living transmission stage. Ciliate sizes are also compared between infected euphausiids that died with and without bursting. SE = standard error

\begin{tabular}{|c|c|c|c|c|c|c|c|c|c|}
\hline \multirow{2}{*}{ Ciliate stage } & \multirow{2}{*}{$\begin{array}{l}\text { Number } \\
\text { of kineties }\end{array}$} & \multirow[t]{2}{*}{$\mathrm{n}$} & \multicolumn{3}{|c|}{ Length, $\mu \mathrm{m}(\mathrm{L})$} & \multicolumn{3}{|c|}{${ }_{-}$Width, $\mu \mathrm{m}(\mathrm{W})$} & \multirow{2}{*}{$\begin{array}{l}\mathrm{W} / \mathrm{L} \\
\text { ratio }\end{array}$} \\
\hline & & & Average & Range & SE & Average & Range & SE & \\
\hline Trophont & $18,20,22$ & 14 & 35.2 & $26.9-82.0$ & 3.8 & 19.3 & $13.2-51.0$ & 2.5 & 0.55 \\
\hline Tomont & $16,18,20$ & 88 & 27.4 & $12.2-58.3$ & 1.2 & 14.9 & $12.0-33.3$ & 0.7 & 0.54 \\
\hline Protomite & 18,20 & 3 & 28.5 & $21.1-36.0$ & 3.7 & 19.1 & $11.2-28.1$ & 2.9 & 0.67 \\
\hline Tomitogenesis & 14 to 20 & 37 & 23.0 & $15.9-36.7$ & 0.9 & 19.0 & $10.0-28.3$ & 0.8 & 0.82 \\
\hline Tomite & 14,16 & 4 & 31.8 & $19.0-37.5$ & 4.3 & 25.8 & $15.5-30.0$ & 3.5 & 0.81 \\
\hline Burst (Tomite) & & 78 & 30.4 & $16.0-58.3$ & 1.1 & 20.2 & $11.5-33.3$ & 0.6 & 0.67 \\
\hline $\begin{array}{l}\text { Not burst (combination } \\
\text { Tomont-Tomite) }\end{array}$ & & 70 & 24.3 & $12.2-82.0$ & 1.4 & 12.9 & $12.0-51.0$ & 0.8 & 0.53 \\
\hline
\end{tabular}
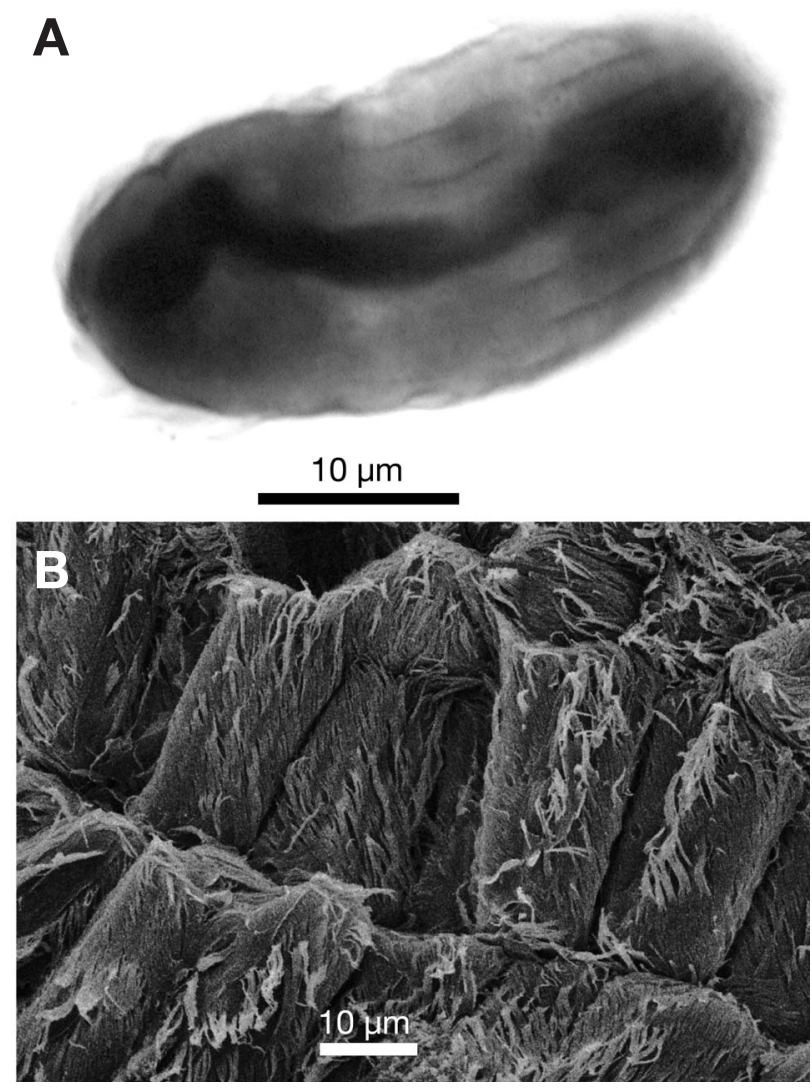

Fig. 3. Collinia oregonensis n. sp. (A) Feeding ciliate stage (trophont) using the modified Protargol staining technique. (B) Highly packed ciliates in the hemocoel of the euphausiids where the ciliates form rectangular shapes

in the abdomen and appendages that are relatively more transparent than the orange colored carapace. The flexible ciliates can squeeze through small passageways of core tissues, moving anterior end first. The tomont divides repeatedly within the euphausiid's body cavity until tomites are formed.
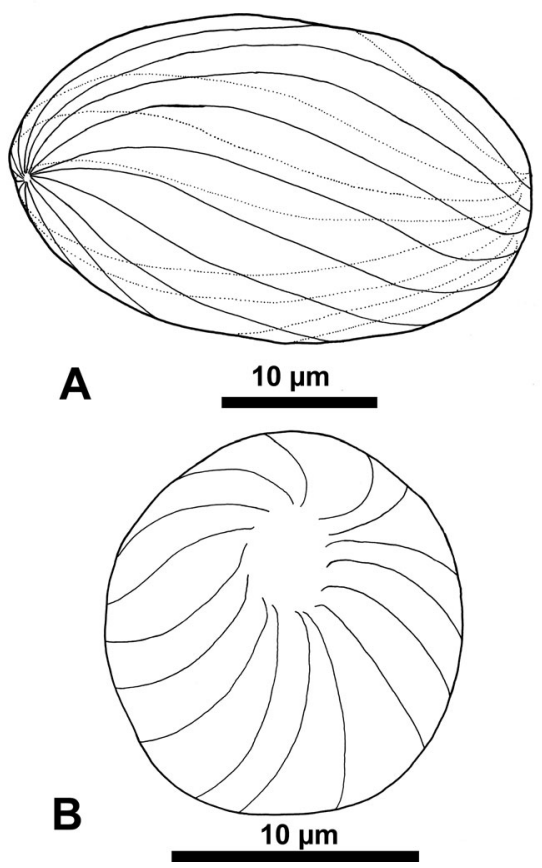

Fig. 4. Collinia oregonensis n. sp. Feeding ciliate stage (trophont) using the modified Protargol staining technique. (A) Lateral view, (B) posterior view of the cell

Protomite: Variable, even numbers of kineties (16, 18 , and 20) extend from pole to pole without spiraling. The length of the cells ranged from 21 to $36 \mu \mathrm{m}$ and the width from 11 to $28 \mu \mathrm{m}$ (Table 1). The cells have a less elliptical shape (0.67 length/width ratio).

Tomitogenesis: The tomont undergoes palintomy, and with each successive division the kineties shorten and straighten. Daughter cells may or may not be of equal size (Table 1) and it is not known how many tomites are produced from each tomont (Figs. 1F \& 2F). However, since the tomites are large in comparison to the trophont and tomont, it is likely that only few 
sequential divisions occur. The tomites do not form chains of cells before division (serial division). Hematoxylin stain counterstained with Fast Green (Fig. 6A-D) reveals that the tomont is vacuolate, often with a single central vacuole, its macronucleus is composed of distinctly clumped and swirling chromatin, and it possesses 2 micronucleii (Fig. 6A). A series of micrographs of ciliates reveal the division of the macronucleus (Fig. 6B-D).
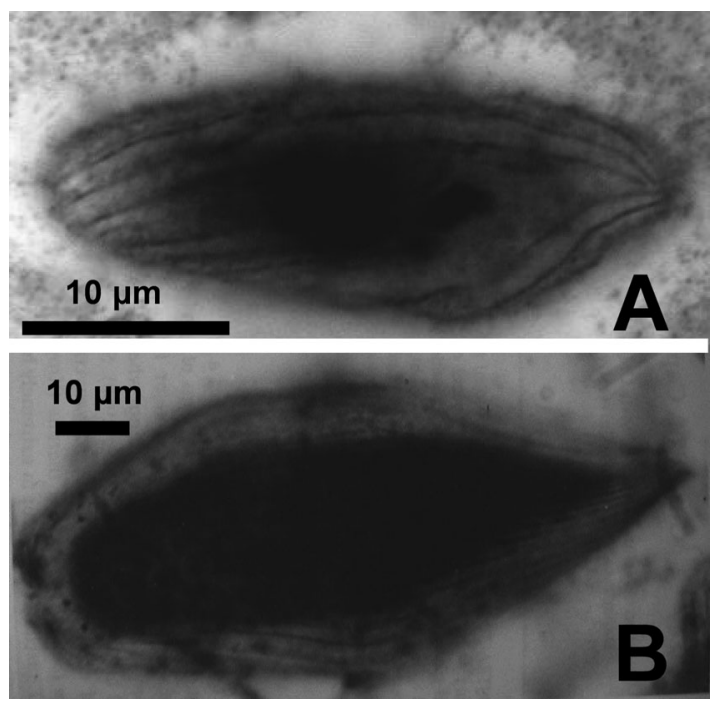

Fig. 5. Collinia oregonensis n. sp. and C. beringensis. Morphological comparison of the reproductive ciliate stage (tomont) of (A) Collinia oregonensis n. sp. (this study) and (B) C. beringensis (Capriulo \& Small 1986). Both were prepared using silver impregnation (modified Protargol) staining technique. C. oregonensis has a smaller nucleus and fewer kineties (20) than $C$. beringensis (34 kineties)
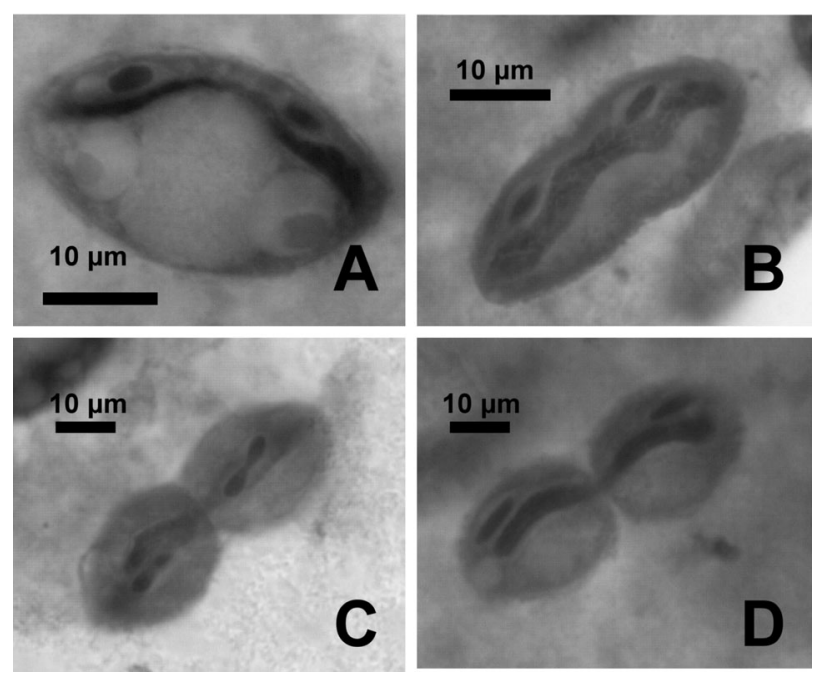

Fig. 6. Collinia oregonensis n. sp. Tomitogenesis cells stained with hematoxylin counterstained with Fast Green in different stages of palintomy. The macronucleus is divided and each daughter cell possesses a micronucleus. All photographs in this figure are courtesy of S. C. Landers (Troy State University, AL)
Tomite: The living tomites are almost spherical (0.81 length/width ratio), 19 to $37 \mu \mathrm{m}$ long and 15 to $30 \mu \mathrm{m}$ wide. They invariably possess reduced numbers of kineties (16 or in a few cases only 14), which extend from pole to pole without spiraling, and bear short cilia or small, rounded buds (Figs. $1 \mathrm{H} \& 2 \mathrm{H}$, Table 1). Tomites break free from the euphausiid body and usually swim off when the euphausiid burst; however, in a few cases the tomites kill the host without bursting it and leave the exoskeleton once they have consumed the complete euphausiid.

Diagnosis: Collinia oregonensis is distinguished from C. beringensis (Capriulo \& Small 1986), which also infects euphausiids, by the smaller number of kineties (14 to 20). C. gammari is the only species in which the number of kineties overlaps with the count in $C$. oregonensis in the trophont stage, but apparently the former species is usually larger than the latter (see Table 3).

Type host: Euphausia pacifica Hansen, 1911.

Type location: North East Pacific, along the Oregon coast, USA, $43^{\circ} 13.20^{\prime} \mathrm{N}, 124^{\circ} 59.40^{\prime} \mathrm{W}$.

Location on host: Endoparasitoid ciliate living in the hemocoel of the euphausiids.

Type of material: Two slides with trophonts and tomonts of Collinia oregonensis (Holotype USNM 1084004 and Paratype USNM 1084005) and 1 Euphausia pacifica female in advanced stage of infection (23.7 mm total length, Non-type USNM 1084006). The material was deposited in the International Protozoan Type Slide Collection of the Department of Invertebrate Zoology of the National Museum of Natural History, Smithsonian Institution, Washington DC, USA.

Etymology: The specific name refers to the geographical location where this parasitoid was discovered.

\section{Life cycle of Collinia oregonensis and signs of infection in euphausiids}

Uninfected live euphausiids have a semi-transparent appearance as all organs (i.e. stomach, intestine, hepatopancreas, heart, and gonad) are visible in the cephalothorax and the abdomen. In the initial stage of infection, the euphausiids have a pale, cream-orange spot below the gonad and posterior to the stomach (Figs. 1A \& 2A). Under laboratory conditions, infected euphausiids turned yellow or cream-orange and developed a swollen carapace between 12 and $24 \mathrm{~h}$ after initial incubation ( $\mathrm{n}=2$ euphausiids), and large numbers of trophonts, sometimes acquiring a rectangular shape, were observed tightly packed inside the cephalothorax (Figs. 1B, 2B \& 3B). As trophonts increase in size and number, the euphausiid cephalothorax swells and 
changes color from pale white to bright orange (Figs. 1C \& 2C). In advanced phases of the infection, the tightly packed ciliates replace all the organs, including the lipid-rich gonads. All stages of Collinia oregonensis are astomatous, indicating they possess an osmotrophic feeding mechanism. The exact nature of host tissue replacement/disintegration is uncertain, but may be a result of metabolites or enzymes released by the proliferating ciliate, which ingest the internal euphausiid biomass by osmotrophy. As in other endoparasitic apostome trophont stages (Chatton \& Lwoff 1935), the mature trophont feeds and increases in cell volume, then begins to enter into a reproductive stage (tomont) (Figs. 1F \& 2F). The tomont divides by palintomy (Figs. 1F \& 2F), to form a non-feeding ovoid dispersal stage (tomite) (Figs. $1 \mathrm{H} \& 2 \mathrm{H}$ ).

Ciliates of the genus Collinia severely affect host behavior prior to death. In shipboard experiments, euphausiids in late stages of infection stopped or greatly reduced their swimming activity. When a high proportion of the ciliates are in cell division (SEM pictures of a sagittally cut euphausiid enabled us to estimate that $>60 \%$ of the cells are in tomitogenesis), the parasites rupture the cephalothorax-abdomen junction, killing the host, and release tomites that then swim inside and outside the euphausiid carcass (Figs. $1 \mathrm{G} \& 2 \mathrm{G}$ ). In about $15 \%$ of cases the euphausiid hosts did not rupture, but the trophonts replaced the remaining body tissues. If $C$. oregonensis has a life cycle similar to other apostome ciliates, the free-swimming tomite stage should encounter a new host to encyst as a phoront and repeat its life cycle; however, we were unable to actually observe this part of the $C$. oregonensis life cycle. After the host ruptured, the carcass content was completely consumed by the ciliates, leaving an empty exoskeleton in less than $12 \mathrm{~h}$. Freeswimming ciliates in experimental bottles (seawater previously sieved with a GF/F filter of $0.22 \mu \mathrm{m}$ pore diameter) usually formed long filaments where the ciliates were densely clustered (under laboratory conditions filament formation usually occurred between 12 and $36 \mathrm{~h}$ after bursting, and SEM micrographs showed clusters of ciliates adhered by mucilaginous material of unknown composition). It is not known whether such filaments are formed under turbulent conditions in the sea.

SEM micrographs of an advanced infected euphausiid stage in sagittal (Fig. 7A) and transversal (Fig. 7C) sections of the cephalothorax indicate that ciliates primarily reside in hemocoel. However, it is interesting that infected euphausiids can remain alive for several days even when heavily parasitized and withstanding a great deal of tissue damage. It is suspected that this damage is a result of lysins or toxins produced by the proliferating parasite. After the euphausiid bursts, the rest of the organism deteriorates (liquefaction of tissue). In uninfected euphausiids, the cephalothorax of a mature healthy female is filled by vitellogenic ovary, digestive gland, and muscles (Fig. 7B,D). Fig. 7D also shows the male's spermatophore attached to the female's thelycum.

Laboratory experiments. The infection mechanism is not known for any of the Collinia species so far described (Collin 1909, Summers \& Kidder 1936, Puytorac 1953, Puytorac \& Lom 1962, Puytorac \& Grain 1975, Capriulo \& Small 1986, Capriulo et al. 1991). Therefore, in the present study several experiments were performed to determine the possible infection mechanism. There is no observational or experimental evidence to suggest that the ciliate can infect the euphausiid by ingesting released free-swimming tomites. However, this mechanism could explain the high numbers of trophont stages in the early and intermediate stages of infection. An optical microscope photograph of the intestine of an infected euphausiid shows 2 sections with highly aggregated ciliates around it, while other sections of the gut are still unaffected (Fig. 7E). This was observed in several of the burst euphausiids showing a similar clustered ciliate pattern, which suggests that these are points where the ciliate originally infected the host (from the intestine duct toward the hemocoel). Another possibility is that ciliates may be drawn to these points by a high concentration of absorbed food (osmotrophs), thus C. oregonensis may be a conventional parasite in early stages of infection and convert to parasitoid status as the infection progresses toward the death of the host.

Healthy euphausiids exposed to free-swimming tomites never became infected under shipboard laboratory conditions. Most of the healthy euphausiids molted on regular schedules and none of them became infected even after 7 to $10 \mathrm{~d}$ of observation, possibly indicating that euphausiids may have an effective defense mechanism to prevent infection. This hypothesis is supported by observations of initially healthy hosts with experimentally induced wounds exposed to free-swimming Collinia oregonensis from a ruptured infected host. Ciliates clustered around the experimentally induced wounds, but the euphausiid died without showing clinical signs of infection (swollen orange cephalothorax). Furthermore, dissection of originally healthy individuals exposed to infected euphausiids did not show evidence of ciliate infection. Future laboratory infection experiments should consider the possibility that (1) infection could require a longer exposure and/or maturation period than that of our shipboard experiments and (2) that ciliates may use alternative or intermediate hosts before they infect euphausiids.

Host/parasitoid interactions. The total length of euphausiids infected with the endoparasitoid (trophont 

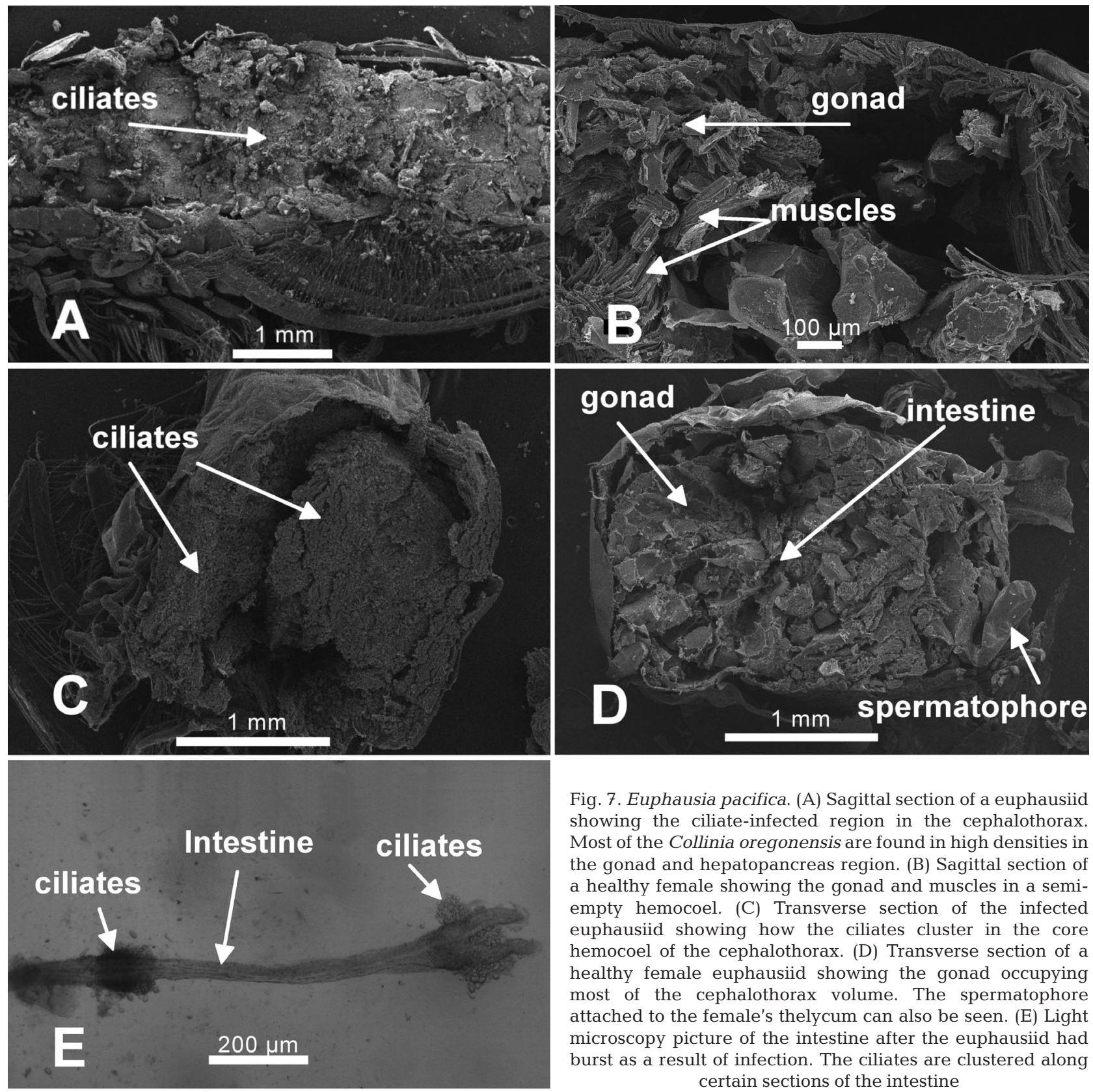

Fig. 7. Euphausia pacifica. (A) Sagittal section of a euphausiid showing the ciliate-infected region in the cephalothorax. Most of the Collinia oregonensis are found in high densities in the gonad and hepatopancreas region. (B) Sagittal section of a healthy female showing the gonad and muscles in a semiempty hemocoel. (C) Transverse section of the infected euphausiid showing how the ciliates cluster in the core hemocoel of the cephalothorax. (D) Transverse section of a healthy female euphausiid showing the gonad occupying most of the cephalothorax volume. The spermatophore attached to the female's thelycum can also be seen. (E) Light microscopy picture of the intestine after the euphausiid had burst as a result of infection. The ciliates are clustered along certain sections of the intestine

to tomite stages) ranged from 16 to $25.5 \mathrm{~mm}$ for Euphausia pacifica (Fig. 8A) and 15 to $27 \mathrm{~mm}$ for Thysanoessa spinifera (Fig. 8B). Prevalence increased with size of the host for E. pacifica but this trend was not clear for $T$. spinifera. Only 1 adult $T$. gregaria, infected by Collinia oregonensis was collected and measured $12.8 \mathrm{~mm}$ total length. Endoparasitic stages of $C$. oregonensis were collected mostly from adult female euphausiids $(91 \%, \mathrm{n}=51)$. No infected larvae or juveniles were found during 68 shipboard molting rate experiments $(n=1873$ euphausiids incubated by Tracy Shaw et al., Hatfield Marine Science Center,
Newport, Oregon, pers. comm.), suggesting that those stages are seldom, if ever, infected by C. oregonensis.

The average time between early ciliate infection and the death of the euphausiid by bursting was $41 \mathrm{~h}$ (SE \pm $9.3 \mathrm{~h}, \mathrm{n}=9$ ), and those that did not burst died within $77 \mathrm{~h}$ after infection ( $\mathrm{SE} \pm 7.7 \mathrm{~h}, \mathrm{n}=9$ ). The time of the host's death after infection was significantly positively associated with host biomass expressed as body carbon weight (Fig. 8C). Thus, as host biomass increases, the time spent inside the host also increases, suggesting that the number of ciliate cells is proportional to body biomass. Several infected euphausiids molted, 

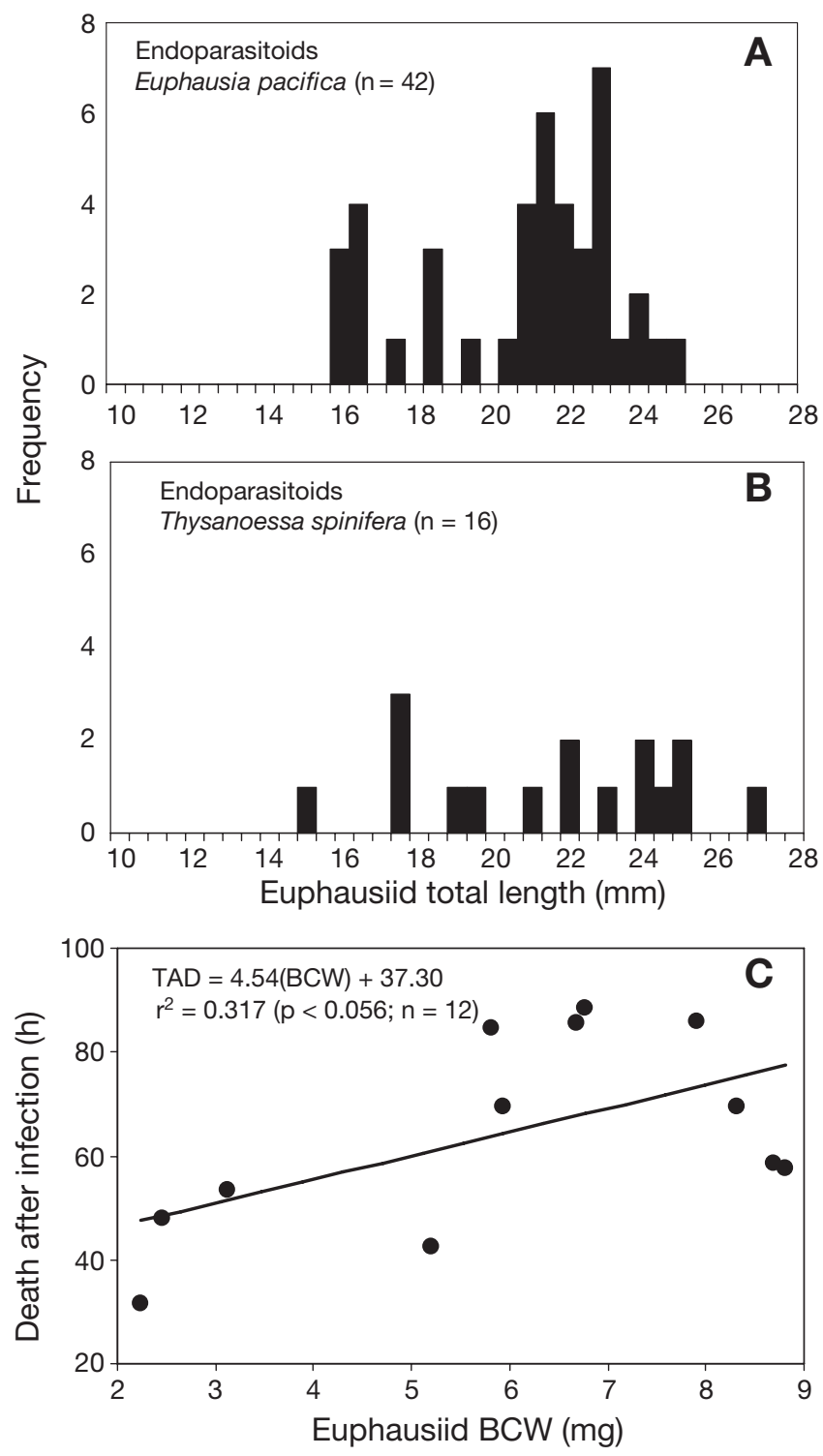

Fig. 8. Collinia oregonensis n. sp. Size frequency distribution of the total length (from the posterior part of the eye to the tip of the telson) of infected sub-adult and adult euphausiids of (A) Euphausia pacifica $(\mathrm{n}=42)$ and (B) Thysanoessa spinifera $(\mathrm{n}=16)$ collected during 2 summer oceanographic cruises in 2002 along the Oregon coast. (C) Linear regression between the time of death after infection (TAD, h) and the euphausiid body carbon weight (BCW, mg $\mathrm{C}$ ind. ${ }^{-1}$ ) for E. pacifica and T. spinifera combined

but without an increase in body length (measured from the difference of the uropod length from the molt and the uropod of the dead animal), as observed in uninfected individuals $(n=5)$. Mature infected females never spawned, probably because they were less fit than uninfected individuals $(\mathrm{n}=46)$.

Table 2 shows the prevalence and geographic location of 28 sampling stations where infected euphausiids were collected $(n=73)$. Infected specimens were collected at $6.7 \%$ of the stations (MOCNESS and $1 \mathrm{~m}$ diameter nets, $\mathrm{n}=313$ ) during 10 oceanographic cruises conducted between 2000 and 2002. Stations were distributed mostly near the shelf-break (150 to $300 \mathrm{~m}$ depth). No infected euphausiids were recorded during a winter cruise (January to February, 2003, n = 41 zooplankton samples). The prevalence ranged between 3 and $20 \%$ of all euphausiids within individual samples, but in 3 locations all the specimens collected were infected (Table 2). However, because the parasitoidism is easily identified only during the late stages of infection (orange and swollen carapace), the estimates of prevalence of infected individuals are conservative.

\section{DISCUSSION}

\section{Taxonomy of the genus Collinia}

The taxonomy of the genus Collinia is based primarily on the morphology of endoparasitic stages because other life history stages (e.g. protomite, tomite?) appear to be similar for all apostome ciliate species. It is important to note that virtually nothing is known about their exoparasitic stages. This is in contrast to other apostome genera like the exuviotrophic ciliates of the genus Gymnodinoides where the exoparasitic stages, such as the tomites, are frequently used to distinguish among species (Bradbury 1994, Landers et al. in press). It is likely that parasitoid ciliates like Collinia sp. infect other euphausiid species of the world oceans. However, they may easily be overlooked because euphausiids can only be recognized as infected when they are alive. In addition, zooplankton samples are usually preserved in formalin immediately after sampling, causing infected euphausiids to lose color rapidly, and thus infected individuals could escape detection. Capriulo et al. (1991) claimed that euphausiids densely packed with ciliates and fixed with formalin or Bouin's fixatives have a 'cloudy' or opaque white appearance. Observations during dissection of females to stage gonad development (Gómez-Gutiérrez 2003, $\mathrm{n}=625$ females) indicate that after preservation even healthy adult euphausiids, particularly Thysanoessa spinifera, can have a swollen carapace with whitish coloration not associated with Collinia parasitism. Therefore, caution must be exercised when looking for infected individuals in preserved samples.

The family Colliniidae has 2 genera, Collinia and Metacollinia (Lynn 2002, Lynn \& Small 2002). The genus Collinia currently has 7 described species including $C$. oregonensis, each of which infects different crustacean hosts (Capriulo \& Small 1986, see their Table 1). In addition, Capriulo \& Small (1986) reported 
Table 2. Geographical distribution and prevalence of the endoparasitoid Collinia oregonensis n. sp. that infects the euphausiids Euphausia pacifica (Ep), Thysanoessa spinifera (TS), and T. gregaria (Tg) along the Oregon coast (September 2000 to August 2002). The collection method is given in parentheses; $B=$ Surface bucket; $1-\mathrm{m}=1 \mathrm{~m}$ net mouth diameter with $0.333 \mathrm{~mm}$ mesh net; $\mathrm{BN}=$ Bongo net with $0.333 \mathrm{~mm}$ mesh net; $\mathrm{M}=$ MOCNESS $1 \mathrm{~m}^{2}$ mouth with $0.333 \mathrm{~mm}$ mesh net; ROPOS = vacuum tube collection with a remotely operated vehicle during an E. pacifica mass mortality event reported by Gómez-Gutiérrez et al. (2003). Infected euphausiids were also discovered during euphausiid egg production rate (EPR) experiments, MR = molting rate experiments $\mathrm{G}=$ female gonad dissection for maturity stage; $\mathrm{QS}=$ qualitative sample. All samples were collected at night

\begin{tabular}{|c|c|c|c|c|c|}
\hline $\begin{array}{l}\text { Date } \\
\mathrm{dd} / \mathrm{mm} / \mathrm{yy}\end{array}$ & Location $\left({ }^{\circ} \mathrm{N},{ }^{\circ} \mathrm{W}\right)$ & $\begin{array}{l}\text { Sample depth }(\mathrm{m}) \\
\text { and collection } \\
\text { method }\end{array}$ & $\begin{array}{c}\text { Host } \\
\text { species }\end{array}$ & $\begin{array}{l}\text { Euphausiid } \\
\text { abundance }\end{array}$ & $\begin{array}{c}\text { Prevalence (\%) } \\
\text { and (no. of hosts } \\
\text { infected) }\end{array}$ \\
\hline 09/07/00 & $43^{\circ} 13.20^{\prime}, 124^{\circ} 59.40^{\prime}$ & Surface (B) & $E p$ & QS & $100.0(\mathrm{n}=21)$ \\
\hline $13 / 07 / 00$ & $44^{\circ} 00.00^{\prime}, 125^{\circ} 00.00^{\prime}$ & $20(1-\mathrm{m})$ & $E p$ & QS & $100.0(\mathrm{n}=2)$ \\
\hline 28/06/01 & $46^{\circ} 21.24^{\prime}, 124^{\circ} 51.42^{\prime}$ & 600 (ROPOS) & $E p$ & $<47$ ind. $\mathrm{m}^{-2}$ & $100.0(\mathrm{n}=7)$ \\
\hline 30/07/01 & $44^{\circ} 38.99^{\prime}, 124^{\circ} 39.11^{\prime}$ & $20(\mathrm{BN})$ & $E p$ & $(\mathrm{n}=14), \mathrm{G}$ & $7.1(\mathrm{n}=1)$ \\
\hline 05/08/01 & $44^{\circ} 38.99^{\prime}, 124^{\circ} 39.00$ & $20(\mathrm{BN})$ & $E p$ & $(\mathrm{n}=28), \mathrm{G}$ & $3.6(n=1)$ \\
\hline 19/09/01 & $44^{\circ} 38.99^{\prime}, 124^{\circ} 39.11^{\prime}$ & $20(1-m)$ & Ts & $(n=5) E P R$ & $20.0(\mathrm{n}=1)$ \\
\hline 03/03/02 & $44^{\circ} 39.10^{\prime}, 124^{\circ} 31.69^{\prime}$ & $20(\mathrm{BN})$ & $T s$ & $(\mathrm{n}=14), \mathrm{G}$ & $7.1(\mathrm{n}=1)$ \\
\hline 03/06/02 & $42^{\circ} 20.99^{\prime}, 124^{\circ} 42.00^{\prime}$ & $20(1-m)$ & Ts & $(n=12) E P R$ & $16.7(\mathrm{n}=2)$ \\
\hline 03/06/02 & $42^{\circ} 20.99^{\prime}, 124^{\circ} 42.00^{\prime}$ & $20(1-m)$ & $T s-E p$ & $(\mathrm{n}=30) \mathrm{MR}$ & $6.7(\mathrm{n}=2)$ \\
\hline $11 / 06 / 02$ & $43^{\circ} 45.01^{\prime}, 124^{\circ} 19.20^{\prime}$ & $20(1-m)$ & $T s$ & $(n=12)$ EPR & $8.3(\mathrm{n}=1)$ \\
\hline $12 / 06 / 02$ & $43^{\circ} 12.99^{\prime}, 124^{\circ} 45.06^{\prime}$ & $20(1-m)$ & TS & $(n=7)$ EPR & $14.3(\mathrm{n}=1)$ \\
\hline $12 / 07 / 02$ & $41^{\circ} 54.36^{\prime}, 124^{\circ} 30.30^{\prime}$ & $0-20(\mathrm{M})$ & TS & QS & $(\mathrm{n}=1)$ \\
\hline $12 / 07 / 02$ & $41^{\circ} 54.54^{\prime}, 124^{\circ} 36.72^{\prime}$ & $0-10(\mathrm{M})$ & $T s$ & $\mathrm{n}=30$ & $3.33(\mathrm{n}=1)$ \\
\hline 01/08/02 & $44^{\circ} 15.07^{\prime}, 124^{\circ} 54.00^{\prime}$ & $0-20,200-250(\mathrm{M})$ & $T s-E p$ & QS & $(\mathrm{n}=4)$ \\
\hline 02/08/02 & $44^{\circ} 15.03^{\prime}, 124^{\circ} 41.10^{\prime}$ & $20(1-\mathrm{m})$ & $T s$ & QS & $3.33(\mathrm{n}=1)$ \\
\hline 06/08/02 & $41^{\circ} 53.99^{\prime}, 124^{\circ} 24.02^{\prime}$ & $20(1-\mathrm{m})$ & $T s$ & QS & $(\mathrm{n}=4)$ \\
\hline 08/08/02 & $42^{\circ} 44.17^{\prime}, 125^{\circ} 24.60^{\prime}$ & $50-70(\mathrm{M})$ & $\mathrm{Tg}$ & QS & $(\mathrm{n}=1)$ \\
\hline 08/08/02 & $44^{\circ} 38.98^{\prime}, 124^{\circ} 39.11^{\prime}$ & $150-200(\mathrm{M})$ & $E p$ & QS & $(\mathrm{n}=1)$ \\
\hline 09/08/02 & $44^{\circ} 39.09^{\prime}, 124^{\circ} 24.76^{\prime}$ & $20(1-\mathrm{m})$ & TS & QS & $(\mathrm{n}=1)$ \\
\hline $12 / 08 / 02$ & $43^{\circ} 51.89^{\prime}, 124^{\circ} 29.96^{\prime}$ & $20(1-m)$ & $E p$ & QS & $(\mathrm{n}=1)$ \\
\hline $13 / 08 / 02$ & $42^{\circ} 57.02^{\prime}, 124^{\circ} 49.13^{\prime}$ & $20(1-m)$ & TS & QS & $(\mathrm{n}=2)$ \\
\hline $13 / 08 / 02$ & $42^{\circ} 57.02^{\prime}, 124^{\circ} 49.13^{\prime}$ & $20(1-m)$ & TS & QS & $(\mathrm{n}=2)$ \\
\hline $13 / 08 / 02$ & $42^{\circ} 57.15^{\prime}, 124^{\circ} 39.93^{\prime}$ & $20(1-\mathrm{m})$ & TS & QS & $(\mathrm{n}=6)$ \\
\hline $15 / 08 / 02$ & $42^{\circ} 57.04^{\prime}, 124^{\circ} 49.10^{\prime}$ & $20(1-m)$ & Ts & QS & $(\mathrm{n}=2)$ \\
\hline $17 / 08 / 02$ & $44^{\circ} 59.93^{\prime}, 125^{\circ} 00.03^{\prime}$ & $20(1-m)$ & $E p$ & QS & $(\mathrm{n}=2)$ \\
\hline $18 / 08 / 02$ & $44^{\circ} 00.36^{\prime}, 125^{\circ} 00.61^{\prime}$ & $20(1-\mathrm{m})$ & $E p$ & QS & $(\mathrm{n}=1)$ \\
\hline $19 / 08 / 02$ & $44^{\circ} 00.37^{\prime}, 125^{\circ} 00.78^{\prime}$ & $10-20(\mathrm{M})$ & $E p$ & QS & $(\mathrm{n}=1)$ \\
\hline $19 / 08 / 02$ & $44^{\circ} 38.99^{\prime}, 124^{\circ} 39.11^{\prime}$ & $100-150(\mathrm{M})$ & $E p$ & QS & $(\mathrm{n}=2)$ \\
\hline
\end{tabular}

the kinetal number, morphology and biometry of an undescribed Collinia species that infects a freshwater subterranean crustacean, Bactrurus mucronatus, but they did not assign it a formal scientific species name. Each species of Collinia has a different number of kineties (Table 3). C. oregonensis n. sp. is the second Collinia species known to infect euphausiids, and the second to be confirmed infecting multiple-host species (C. gammari was reported in Pallasea cancelloides and Echinogammarus maaki; Capriulo \& Small 1986). The first report of an endoparasitic apostome ciliate of euphausiids was C. beringensis from Thysanoessa inermis in the Bering Sea (Capriulo \& Small 1986). However, because their description was based on preserved specimens, the deadly effect of the parasite on the euphausiid host and the signs of infection in live hosts was then unknown. However, they suggested that the ciliate parasites could impair physiological functioning and potentially cause the death of the host.
The incubation of live infected euphausiids allowed us to observe the parasitoid nature of Collinia oregonensis. The present study provides evidence that the ciliates infecting the 3 euphausiid species along the Oregon coast belong to a different species than $C$. beringensis. The most salient feature of the present ciliate is that it possesses fewer kinety rows than $C$. beringensis in all observed stages. Other relevant differences are that all stages of $C$. oregonensis lack a falciform field and a rosette structure, while the protomite 2 stage of $C$. beringensis has both, as well as a $y$ (but not the full $x, y, z$ ) kinetid arrangement. However, all the described stages of $C$. oregonensis and $C$. beringensis are astomatous, indicating an osmotrophic feeding mechanism. This suggests that enzymes, toxins or other metabolites cause tissue disruption. Other apostome ciliates such as Vampyrophrya pelagica Chatton \& Lwoff, 1930 seem to ingest fragments of tissues (histophagous) rather than fluids, using a cytostome 


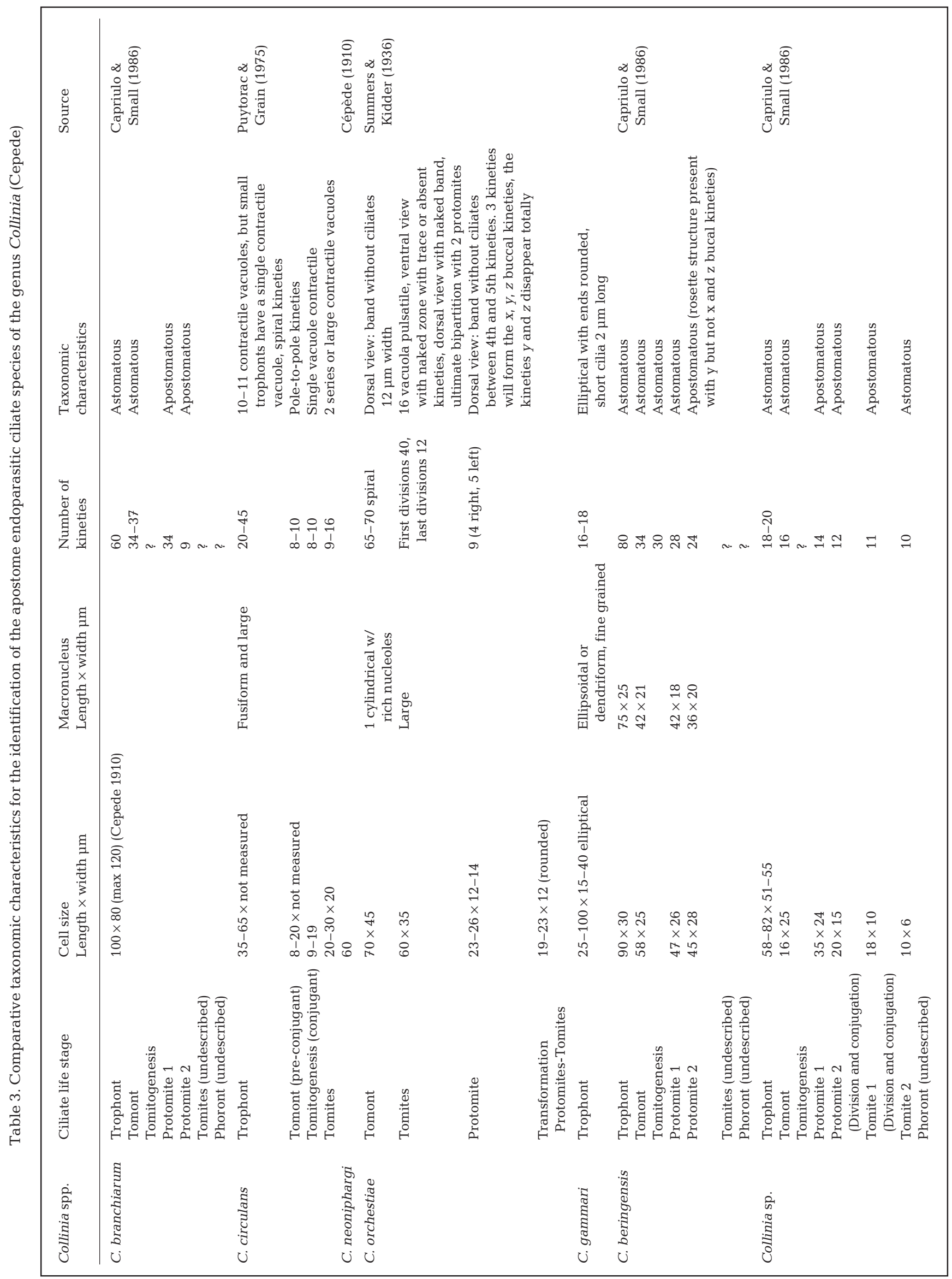


(Grimes \& Bradbury 1992, Ohtsuka et al. 2004). C. beringensis appears to reduce the number of kineties through its endoparasitic stages starting with 80 (trophont), followed by 34 (tomont), 30 (during tomitogenesis), 28 (protomite 1), and 24 (protomite 2). The mature trophont of the endoparasitoid ciliate $V$. pelagica, which infects several copepod species, bears only 10 long and 3 short ( $x, y$ and $z$ ) kineties and it is slightly larger $(50-90 \times 30-50 \mu \mathrm{m})$ than trophonts of $C$. oregonensis (Chatton \& Lwoff 1935, Grimes \& Bradbury 1992, Ohtsuka et al. 2004).

Collinia oregonensis shows a smaller variability in number of kineties than $C$. beringensis, maintaining 20 or 22 kineties in the trophont, 16, 18 or 20 in the tomont and protomite stages, and reducing to 14 or 16 kineties in the tomite stage. However, in relatively few cells a progressive reduction in the number of kineties occurred as early as the trophont or tomont stages (Table 1). The reduction in the number of kineties throughout the life stages, also known as reabsorption of kineties, has been observed in other species of the genus Collinia (Table 3). This phenomenon also occurs in other apostome species; for example, the cilia of Hyalophysa chattoni Bradbury, 1966 are absorbed by the cell in situ, followed by the absorption of the kinetosomes without the withdrawal of the structures into the cytoplasm (Landers 1997). Both C. oregonensis and C. beringensis presumably have a similar life-cycle, having, so far as we know, euphausiids as the definitive host. Also, the structure of the trophont, tomont, and protomite stages is known for both C. oregonensis and $C$. beringensis, whereas the tomite and the phoront stages of $C$. beringensis and the phoronts of C. oregonensis are still unknown. Although the phoront stages of $C$. oregonensis were actually observed attached to the filaments under laboratory conditions, we did not use silver impregnation staining for the description of this stage because of problems with filament preservation.

When Cépède (1910) proposed the genus Collinia, he included Collinia circulans Balbiani, 1885, C. branchiarum Stein, 1852 (synonyms Opalina branchiarum or Anoplophrya branchiarum), and C. neophargi Cépède, 1910 (synonym Anoplophrya branchiarum). His identification key was based on the size of the ciliate and the host that the apostome ciliate infected. In the past almost all known species of the genus Collinia were in the past considered or originally described as members of the genus Anoplophrya, with the exception of the most recently described species $C$. beringensis (Capriulo \& Small 1986) and C. oregonensis nov. sp. Most species of the genus Collinia share the following features: trophonts are small, ovoid, pointed at rear, with no ogival field or lateral canal. The dorsal surface of several Collinia species is largely unciliated and their tomites bear 9 kineties, characteristics not shared by C. oregonensis. Bradbury $(1966,1994)$ proposed that the smaller number of kineties (9) in the tomite stage of apostome ciliates is a primitive (plesiomorphic) characteristic. Thus, the C. oregonensis tomite stage with 14 or 16 kineties is perhaps a derived (apomorphic) condition within the order Apostomatida.

\section{Biology and life cycle of Collinia oregonensis n. sp.}

Two remaining problems to be researched in connection with the life history of Collinia oregonensis are to discover (1) the phoront stage and (2) the infection mechanism of this parasitoid. In the present study, apostome phoronts and encysted tomites were commonly observed attached to the appendage setae of at least 6 euphausiid species (Euphausia pacifica, Thysanoessa spinifera, T. gregaria, T. longipes Brandt, 1851, T. inspinata Nemoto, 1963, and Nematoscelis difficilis Hansen, 1911), with prevalence of about $80 \%$ in the juvenile and adult populations, but silver staining revealed a ciliary pattern inconsistent with the genus Collinia and most likely belonging to the genus Gymnodinioides (Landers et al. in press). Additionally, several euphausiids with phoronts attached to the setae were intentionally wounded, but the phoronts did not excyst or enter the wound like other apostome ciliates (e.g. Vampyrophrya pelagica) (Grimes \& Bradbury 1992, Ohtsuka et al. 2004), suggesting that these euphausiids are interacting with at least 2 different kinds of apostome ciliates (1 exuviotrophic and 1 endoparasitoid). Shipboard experiments with euphausiids bearing encysted phoront stages incubated in water previously GF/F filtered convincingly showed that phoronts excysted and became trophonts of exuviotrophic ciliates immediately after the euphausiids molted (S. C. Landers pers. comm.). Moreover, it was subsequently shown that the abundant phoronts belong to apostome ciliate groups that feed on the exuvial fluids trapped in the cast-off exoskeleton recently described as Gymnodinioides pacifica nov. sp. (Landers et al. in press).

The resting cysts (phoront stage) of epibiontic apostome ciliates were frequently recorded attached to appendages (3 to $20 \%$ prevalence) of 9 euphausiids in the North Atlantic (Euphausia hemigibba Hansen, 1910, E. krohni Brandt, 1851, Meganyctiphanes norvegica M. Sars, 1857, Nyctiphanes couchi Bell, 1853, Nematoscelis megalops G.O. Sars, 1883, Thysanoessa gregaria, T. inermis, T. longicaudata Krøyer, 1946, and T. raschi M. Sars, 1864) by Lindley (1978). Distributions of the last 5 euphausiid species extend to the North Pacific Ocean, so these species may have the 
same kind of epibionts and exuviotrophic apostome ciliates as described by Landers et al. (in press).

Regarding the infection mechanism of Collinia oregonensis, it is well known that the 2 greatest challenges any parasite faces are moving itself or its progeny from one host to another (transmission), and overcoming the host's defenses. Since it appears that only adult euphausiids are infected, transmission must be among hosts within a population and via the external environment, rather than from parents to offspring. However, it is possible, although we think it unlikely, that C. oregonensis infects juveniles and that infection accelerates as the host matures. The parasitic ciliates of the order Apostomatida are known to infect their crustacean hosts by breaching the cuticle or by entering through wounds (Morado \& Small 1995). In the first mode, secretion from the ciliate dissolves a passage through the cuticle (Bradbury 1994). Apostome ciliates such as Synophrya or Terebrospira break through the host cuticle of the gill lamellae, causing extensive tissue damage (Bradbury \& Goyal 1976, Johnson \& Bradbury 1976). However, not all apostome ciliates are invasive or capable of perforating epithelia. In the second mode, infection can occur when the host has been wounded by predators. This is the infection mechanism of the ciliate Vampyrophrya pelagica on several calanoid, harpaticoid, cyclopoid and poecilostomatoid copepod species (Grimes \& Bradbury 1992, Ohtsuka et al. 2004). We conducted experiments to infect healthy or experimentally wounded euphausiids ( $>10$ euphausiids per experiment with controls), but none of the experiments were successful in inducing infections (that is, no experiment resulted in a euphausiid with an orange-colored, swollen cephalothorax).

Conventional knowledge about the life cycle of the apostome ciliates indicates that reproduction occurs only in the tomont stage, and that the trophont stage is exclusively a feeding stage. However, the SEM images of an infected euphausiid showed densely packed trophonts in the hemocoel; therefore, if the trophont does not divide, this may indicate a massive infection of the host, otherwise it is not possible to explain the large number of this stage in the host carapace, indicating that Collinia oregonensis may use a different, hitherto unknown infection mechanism. As a first approach, we propose a hypothetical infection mechanism that might be used by $C$. oregonensis: the dispersal stages (tomites) may be eaten by the euphausiid and then penetrate the stomach or intestine to enter into the hemocoel. However, we have as yet been unable to successfully show this mechanism in exposing healthy euphausiids to free swimming tomites recently released from a bursted host. Another hypothesis is that euphausiids may become infected after feeding on the filaments that form several hours after the euphausiid has burst. Interestingly, Grimes \& Bradbury (1992) reported that when the tomites settled during the encystation process, they appeared to attach by fine filaments to the copepod (host) exoskeleton. Recently, for gregarines (Apicomplexa: Engregarinida) in the gamont stage, infection was discovered on the euphausiid Euphausia superba Dana, 1850. The gregarines infected the midgut gland and intestinal epithelium of the euphausiid, having a significant impact on the nutritional status of the host (Kawaguchi \& Toda 1997, Kawaguchi et al. 1999, Takahashi et al. 2003). In our study, recently ruptured euphausiids frequently possessed portions of intact intestine, with some areas densely packed with ciliates.These may represent the points where the ciliates originally infected the euphausiids (Fig. 7E), but this remains speculative.

We found a biased sex proportion (more females) of euphausiids (Euphausia pacifica and Thysanoessa spinifera) infected by endoparasitic stages of Collinia oregonensis. The fact that the ciliate more frequently infects females might have an important effect on the population's sex ratio, decreasing the spawning stock and population egg production, since infected females never produced eggs. However, the effect of infection on sex ratio is ambiguous. Sex-biased mortality in euphausiids has been reported, but not associated with parasitism. For example, mortality of E. superba is higher for reproductive males (with low lipid levels) than for females (high lipid levels) (Virtue et al. 1996). However, other studies suggest that, in general, male and female arthropods do not differ in prevalence or intensity of parasite infections due to similarities in the host's digestive physiology and foraging ecology (Sheridan et al. 2000). C. oregonensis may impose a strong energy constraint because infected euphausiids that molted did not increase in total length (measured from the uropod length of the molt and the just molted animal). C. beringensis infection of the euphausiid T. inermis includes primarily adult stages $(>3.8 \mathrm{~mm}$ carapace length equivalent to $>14 \mathrm{~mm}$ total length) also with a relatively higher proportion of females (Capriulo et al. 1991). The Collinia infection mechanism and why apparently the parasitoid ciliates prefer to infect females are 2 questions to be addressed in future studies.

The size of first maturity for Euphausia pacifica is about $12 \mathrm{~mm}$ (Ross \& Quetin 2000) and for Thysanoessa spinifera about $15 \mathrm{~mm}$ (Gómez-Gutiérrez 2003), thus all endoparasitically infected euphausiids were most likely adults (see Fig. 8A,B). Yolk accumulation is the most energy-demanding process for euphausiids, and is usually linked with high grazing rates and metabolism. The high energetic content of the female gonad (Pierce et al. 1969) certainly could provide a rich food resource that would allow for rapid 
proliferation of Collinia oregonensis. However, parasitoid ciliates may prefer to infect adults early in the gonadal maturation cycle since it is known that euphausiids such as Meganyctiphanes norvegica lose between 33 and $55 \%$ of their cephalothorax lipids through spawning (Albessard \& Mayzaud 2003). From an evolutionary perspective, the ciliates may primarily infect adults, since this helps to maximize the food available to support a high production of ciliates with which to infest other euphausiids. The infection of males may impose a lipid content limitation (see Virtue et al. 1996) and larvae and juveniles are usually not infected, perhaps because of their low body biomass (usually $<2 \mathrm{mg} \mathrm{C}$ ind. ${ }^{-1}$ ) and therefore relatively low lipid content. Biologically, the carrying capacity may be proportional to the host biomass and/or the host's energy intake. A positive relationship between the host biomass and the time until death after infection was observed for both euphausiid species, indicating that the parasites in larger hosts will have more time to produce more biomass than parasites in smaller or poorly fed hosts (Fig. 8C). To maximize the parasite fitness, they tend to preferentially infect larger hosts. These observational data support mathematical models proposed by Anderson \& May (1978) and Ebert \& Weisser (1997) which show that it is more effective for the parasite to kill its host later when carrying capacity is higher. Observational data indicate that several apostome ciliates tend to infect the larger animals in the host population, preferentially females (Ohtsuka et al. 2004). Iguchi \& Ikeda (1995), Ross \& Quetin (2000) and Feinberg et al. (2003) reported that E. pacifica reaches maturation size at about $12 \mathrm{~mm}$ total length ( 9 mo old), attaining a maximum size of $25 \mathrm{~mm}$ (estimated life span $\sim 2$ yr). From the size-frequency host vs. prevalence Fig. (Fig. 8A) it is evident that ciliates infect only adults (>16 mm total length), preferring females. E. pacifica interbrood period is usually shorter than $5 \mathrm{~d}$ (Feinberg et al. 2003), thus it is unlikely that the Collinia life cycle, which is also of the order of days, is closely connected to the reproductive cycle. This is in fact a lethal infection that kills the host as soon as the parasites proliferate and invade the body cavity.

The prevalence of Collinia oregonensis on live infected euphausiids during 2002 cruises ranged between 3 and $20 \%$ in individual swarms. However, mass mortality events such as those observed in Astoria Canyon, $46.2^{\circ} \mathrm{N}$, near the mouth of the Columbia River (Gómez-Gutiérrez et al. 2003), indicate that under certain conditions, infection can reach very high prevalence. The analysis of videos recorded from a remotely operated vehicle (ROV) deep in the waters of Astoria Canyon showed dense euphausiid aggregation near the sea floor during daytime (Gómez-Gutiérrez et al. 2003). It is well known that euphausiids can become abundant near topographic features like canyons, and can achieve densities 2 to 3 orders of magnitude greater than background abundances (Greene et al. 1988).

The highest prevalence of infected euphausiids was observed near the shelf-break, where according to Swartzman (2001), Ressler et al. (2005) and GómezGutiérrez et al. (2005) high densities of euphausiid aggregations are commonly recorded. Coevolution of the ciliate among multiple-host euphausiid species (Thysanoessa inermis, Euphausia pacifica, T. spinifera, and $T$. gregaria) should arrive at equilibrium, thus the more host species a parasite relies on, the more virulence it can attain without risk to its own survival. Thus, it is predicted that other Collinia species infect multiple host species. The parasite kills the euphausiid in less than $72 \mathrm{~h}$; this is considered very fast when compared with the life span of the host (1 to 2 yr). This disagrees with the general trend that the lower the host background mortality, the longer the parasite should wait to kill the host (Ebert \& Weisser 1997). Under shipboard conditions the infected euphausiids swam in continuous circles for several hours. They then began to decrease their swimming activity until the animal rested in the bottom of the bottle; death followed. Thus, infected animals in the ocean likely display impaired swimming ability and may sink to the bottom before death. Schooling behavior studies on E. superba Dana indicate that sick or parasitized individuals (opaque or whitish body color) are more abundant near the back of the schools and that some of them fall behind, unable to maintain the pace (Hamner et al. 1983, Hamner 1984). When a diver touched several whitish E. superba individual they broke, showing a small cloud around the carcass, presumably ciliates, thus giving observational evidence that the Antarctic krill could also be infected by parasitoid protozoans (W. Hamner, University of California, Los Angeles, pers. comm.)

The effects of parasitism and diseases on the population dynamics of euphausiids are poorly known. Ebert \& Weisser (1997) and Lafferty \& Kuris (2002) reported that parasitoids such as Collinia oregonensis infect relatively small hosts, usually weighing no more than a few grams, with a relatively short life span. The longer life spans of larger hosts might make the parasitoid strategy a relatively inefficient life history. Parasitoidism on euphausiids could be an important, previously underestimated source of mortality that affects the trophodynamics of these crustaceans within the California Current upwelling ecosystem.

Further interpretation of the results must await specific identification of the phoront stages and better observations and experiments on living, infected euphausiids in order to discover the infection mechanism and complete the knowledge of the parasitoid's life cycle. The evaluation of the role of Collinia orego- 
nensis in the pelagic food web and the infection by apostome parasitoid ciliates of other euphausiid species around the world should be investigated in future studies.

Acknowledgements. We thank A. De Robertis, R. D. Brodeur, S. C. Landers, C. B. Miller, K. C. Jacobson, D. H. Lynn, W. Pearcy, E. Sherr and B. Sherr for helpful criticisms of earlier drafts and the exciting discussions about this parasitoid from the Oregon coast. We particularly thank B. Boyer, a seaman and winch operator on the RV 'Wecoma' and the scientist A. Røstad, who first noticed the bright orange colored krill swimming in the water under the ship's lights, on the evening of July 9, 2000 during NEP US GLOBEC research sampling, and called us onto deck to observe and collect them. We are in debt to L. Feinberg, T. Shaw, J. Keister, A. Røstad, M. Vance, J. Lamb, and C. Vann from Hatfield Marine Science Center and the crew of the research vessels 'Elakha' (OSU), 'Wecoma' (OSU) and 'New Horizon' (SIO) for their collaboration in the collection of the live samples between 2000 and 2003. We thank W. W. Wakefield and R. Embley for their leadership during the ROPOS/Brown operation in Astoria Canyon and A. Soeldner for SEM assistance. We thank 3 referees for the criticism that substantially improved the content of the manuscript. Thanks to G. Keel for his help in the donation process of the specimens to the National Museum of Natural History, Smithsonian Institution. This research was supported by Mamie Markham Research Award from Oregon State University, Hatfield Marine Science Center during 2001-2002 and 2003-2004 to J.G.-G.. The NEP US GLOBEC program (NA860P0589) provided ship time and staff assistance. J.G.G. was supported by an SNI fellowship, by COFAA-IPN, EDIIPN, and a PhD CONACyT grant (122676) to study at Oregon State University. This is Contribution No. 271 of the US GLOBEC program.

\section{LITERATURE CITED}

Albessard E, Mayzaud P (2003) Influence of tropho-climatic environment and reproduction on lipid composition of the euphausiid Meganyctiphanes norvegica in the Ligurian Sea, the Clyde Sea and the Kattegat. Mar Ecol Prog Ser 253:217-232

Anderson RM, May RM (1978). Regulation and stability of host-parasite population interactions. I. Regulatory processes. J Anim Ecol 47:219-247

Balbiani EG (1885) Sur un infusoire cilie parasite du sang de l'Asselle aquatique (Anoplophyra circulans). Zool Suisse 2:277-305

Bradbury PC (1966) The life cycle and morphology of the apostome ciliate, Hyalophysa chattoni n. g. sp. nov. J Protozool 13:209-225

Bradbury PC (1994) Parasitic protozoa of mollusks and crustacea, 2nd edn. In: Kreier JP (ed) Parasitic protozoa, Vol 8. Academic Press, San Diego, CA, p 139-263

Bradbury PC, Goyal V (1976) The fine structure of a parasitic ciliate Terebrospira during ingestion of the exoskeleton of a shrimp Palaemonetes. Tissue Cell 8(4):573-582

Capriulo GM, Small EB (1986) Discovery of an apostome ciliate (Collinia beringensis n. sp.) endoparasitic in the Bering Sea euphausiid Thysanoessa inermis. Dis Aquat Org 1:141-146
Capriulo GM, Pedone MJ, Small EB (1991) High apostome ciliate endoparasite infection rates found in the Bering Sea euphausiid Thysanoessa inermis. Mar Ecol Prog Ser 72: 203-204

Cépède C (1910) Recherches sur les infusoires astomes. Anatomie, biologie, ethologie parasitaire, systematique. Arch Zool Exp Gén 5(3):341-609

Chatton E, Lwoff A (1935) Les ciliés apostomes. 1. Aperçu historique et general étude monographique des genres et des espèces. Arch Zool Exp Gén 77:1-453

Collin B (1909) Les phénomenes de la conjugaison chez Anoplophyra branchiarum Stein. Arch Zool Exp Gén 1: 345-388

Dobson AP, Hudson PJ (1986) Parasites, disease and the structure of ecological communities. Trends Ecol Evol 1: $11-15$

Ebert D, Weisser WW (1997) Optimal killing for obligate killers: the evolution of life histories and virulence of semelparous parasites. Proc R Soc London Ser B 264:985-991

Feinberg LR, Gómez-Gutiérrez J, Shaw T, Peterson WT (2003) Vital rates for Euphausia pacifica off the Oregon coast, compared with populations around the north Pacific. 3rd Int Zooplankton Production Symp (20-23 May 2003), Gijon, Spain. Abstract s 7-18, p 189

Gómez-Gutiérrez J (2003) Comparative study of the population dynamic, secondary productivity, and reproductive ecology of the euphausiids Euphausia pacifica and Thysanoessa spinifera in the Oregon upwelling region. $\mathrm{PhD}$ dissertation, Oregon State University, Corvallis, OR

Gómez-Gutiérrez J (2004) Parasitoides unicelulares una epidemia que mata el krill en el Noroeste del Océano Pacífico. Sci Am Latinoam 21:34-35

Gómez-Gutiérrez J, Peterson WT, De Robertis A, Brodeur RD (2003) Mass mortality of krill caused by parasitoid ciliates. Science 301:339

Gómez-Gutiérrez J, Peterson WT, Miller CB (2005) Crossshelf life-stage segregation and community structure of the euphausiids off central Oregon (1970-1972). Deep-Sea Res II 52/1-2:289-315

Greene CH, Wiebe PH, Burczynski J, Youngbluth MJ (1988) Acoustical detection of high-density krill demersal layers in the submarine canyons off George Bank. Science 241: 359-361

Grimes BH, Bradbury PC (1992) The biology of Vampyrophrya pelagica (Chatton and Lwoff, 1930), a histophagous apostome ciliate associate with marine calanoid copepods. J Protozool 39(1):65-79

Hamner WM (1984) Aspects of schooling in Euphausia superba. J Crustac Biol 4:67-74

Hamner WM, Hamner PP, Strand SW, Gilmer RW (1983) Behavior of Antarctic krill, Euphausia superba: chemoreception, feeding, schooling, and molting. Science 20:433-435

Hassell MP, Godfray HCJ (1992) The population biology of insect parasitoids. In: Crawley MJ (ed) Natural enemies: the population biology of predators, parasites and diseases. Blackwell Science Publishers, London, p 265-292

Iguchi N, Ikeda T (1995) Growth, metabolism and growth efficiency of a euphausiid crustacean Euphausia pacifica in Toyama Bay, southern Japan Sea, as influenced by temperature. J Plankton Res 17:1757-1769

Johnson CA, Bradbury PC (1976) Observations of the occurrence of the parasitic ciliate Synophrya in decapods in coastal waters off the southeastern United States. J Protozool 23(2):252-256

Kawaguchi S, Toda T (1997) Discovery of ciliates reproducing in the gut of Antarctic krill. Polar Biol 18:158-160 
Kawaguchi S, Hosie G, Nicol S, Marchant H and 6 others (1999) Do gregarines cause damage to midgut gland and intestinal epithelium of Antarctic krill? Int Symp on krill, Santa Barbara, CA

Lafferty KD, Kuris AM (2002) Trophic strategies, animal diversity and body size. Trends Ecol Evol 17:507-511

Landers SC (1997) Morphogenesis in Hyalophysa chattoni (Ciliophora: Apostomatida): reduction of oral polykineties in encysted phoront. Arch Protistenkd 148:389-397

Landers SC, Gómez-Gutiérrez J, Peterson WT (in press) Gymnodinioides pacifica, n. sp., an exuviotrophic ciliated protozoan (Ciliophora, Apostomatida) from the euphausiids of the North Pacific. Eur J Protistol

Lindley A (1978) Continuous plankton records: The occurrence of apostome ciliates (Protozoa) on Euphausiacea in the North Atlantic Ocean and North Sea. Mar Biol 46:131-136

Lynn DH (2002) The ciliate resource archive. Available at www.uoguelph.ca/ ciliate

Lynn DH, Small EB (2002) Phylum Ciliophora. In: Lee JJ, Bradbury PC, Leedale GF (eds) An illustrated guide to the Protozoa, 2nd edn. Society of Protozoologists, Lawrence, KS, p 371-656

Morado JF, Small EB (1995) Ciliate parasites and related diseases of Crustacea: a review. Rev Fish Sci 3(4):275-354

Nicol S, Endo Y (1999) Krill fisheries: development, management and ecosystem implications. Aquat Living Resour 12: $1-17$

Ohtsuka S, Hora M, Suzaki T, Arikawa M, Omura G, Yamada K (2004) Morphology and host-specificity of the apostome ciliate Vampyrophrya pelagica infecting pelagic copepods in the Seto Inland Sea, Japan. Mar Ecol Prog Ser 282: 129-142

Pierce RW, Van Der Veen J, Olcott HS (1969) Proximate and lipid analyses of krill (Euphausia species) and red crab (Pleuroncodes planipes) J Agric Food Chem 17(2): 367-369

Puytorac P de (1953) Anoplophrya branchiarum (Stein), cilié sanguicole de Gammarus pulex n'est pas un Astome, mais un Apostome. C R Acad Sci 237:1787-1789

Editorial responsibility: Timothy W. Flegel,

Bangkok, Thailand
Puytorac P de, Lom J (1962) La tomitogenèse des Apostomes sanguicoles endoparasites des crustacés. Ann Parasitol Hum Comp 37(31):195-209

Puytorac P de, Grain J (1975) Étude de la tomitogenèse et de l'ultrastructure de Collinia orchestiae, cilié apostome sanguicole, endoparasite du crustacé Orchestia gammarella Pallas. Protistologica 11(1):61-74

Ressler PH, Brodeur RD, Peterson WT, Pierce S D, Vance PM, Røstad A, Barth JA (2005) The spatial distribution of euphausiid aggregations in the Northern California Current during August 2000. Deep-Sea Res II 52:89-108

Ross RM, Quetin LB (2000) Reproduction in Euphausiacea. In: Everson I (ed) Krill biology, ecology and fisheries. Fisheries and Aquatic Resources Series. MPG Books, Bodmin, p 150-181

Sheridan LAD, Poulin R, Ward DF, Zuk M (2000) Sex difference on parasitic infections among arthropod hosts: is there a male bias? Oikos 88:327-334

Summers FM, Kidder GW (1936) Taxonomic and cytological studies on the ciliates associated with the amphipod family Orchestiidae from the Woods Hole district. II. The coelozoic astomatous parasites. Arch Protistenkd 86:379-403

Swartzman G (2001) Spatial patterns of Pacific hake (Merluccius productus) shoals and euphausiid patches in the California Current ecosystem. Spatial processes and management of marine populations. Alaska Sea Grant College Program. AK-SG-01-02, p 495-512

Takahashi KT, Kawaguchi S, Kobayashi M, Toda T (2003) Parasitic eugregarines change their spatial distribution within the host digestive tract of Antarctic krill, Euphausia superba. Polar Biol 26:468-473

Trager W (1957) Excystation of apostome ciliates in relation to molting of their crustacean hosts. Biol Bull Mar Biol Lab (Woods Hole) 112:132-136

Tuffrau M (1967) Perfectionnements et practique de la technique d'impregnation au protargol des infusoires cilies. Protistologica 3:91-98

Virtue P, Nichols PD, Nicol S, Hosie G (1996) Reproductive trade-off in male Antarctic krill, Euphausia superba. Mar Biol 126:521-527

Submitted: September 15, 2005; Accepted: February 13, 2006 Proofs received from author(s): June 7, 2006 